\title{
Influence of Concrete-Pictorial-Abstract (CPA) Approach on the Enhancement of Primary School Students' Mathematical Reasoning Ability
}

\author{
Hafiziani Eka Putri $\bowtie$, Erna Suwangsih1, Puji Rahayu', Gia Nikawanti2, Elfriyani \\ Enzelina', Mukhamad Ady Wahyudy'
}

1 Universitas Pendidikan Indonesia, Bandung, Indonesia

2 STKIP Purwakarta

$\bowtie$ hafizianiekaputri@upi.edu

\begin{abstract}
This research is motivated by the importance of mathematical reasoning abilities for primary school students. This research aims at looking at the effect of the Concrete-PictorialAbstract (CPA) approach on the enhancement of mathematical reasoning abilities of primary school students. This research method is a quasi-experiment with pre-test and post-test control group design in Mathematics subjects with the theme of data presentation. The research sample consisted of 121 fifth grade students in two primary schools in Bekasi Regency. The test and non-test instruments were involved in this research. The results revealed that there was the influence between the CPA approach and students' mathematical reasoning abilities, and the achievement and enhancement of mathematical reasoning abilities of students who got learning with the CPA approach were better than students who got conventional learning based on all student review and a category of Prior Mathematical Ability (PMA) high, moderate and low. In conclusion, the mathematical reasoning ability of primary school students can be improved by applying the CPA approach.
\end{abstract}

Keywords: Prior Mathematical Ability (PMA), Mathematical Reasoning, Concrete-PictorialAbstract (CPA) approach

How to Cite: Putri, H., Suwangsih, E., Rahayu, P., Nikawanti, G., Enzelina, E., \& Wahyudy, M. (2020). Influence of Concrete-Pictorial-Abstract (CPA) Approach on the Enhancement of Primary School Students' Mathematical Reasoning Ability. Mimbar Sekolah Dasar, 7(1), 119-132. doi:https://doi.org/10.17509/mimbar-sd.v7i1.22574.

INTRODUCTION One of the main issues discussed in the field of mathematics education is how students are able to possess mathematical abilities at every level of education. The ability to think mathematically becomes guidance for all learners to solve life problems (Sumartini and Priatna, 2018). There are many kinds of mathematics abilities needed to be developed in order to improve the quality of learning achievement, and foster students' mindset to face the challenges of the times. Bernard and Senjayawati (2019) said that a human being can develop logical, analytical, systematic, critical, and creative thinking skills, and cooperative abilities applied in daily inhalation through mathematics.

The importance of students mastering mathematical abilities, which is explicitly explained by the Ministry of Education and Culture (Kemendikbud - Kementerian Pendidikan dan Kebudayaan) in the purpose of the school-based Curriculum (KTSP - Kurikulum Tingkat Satuan 
Hafiziani Eka Putri et al., Influence of Concrete-Pictorial-Abstract (CPA) Approach ...

Pendidikan) (2006) that enhanced in the 2013 Mathematics Curriculum, as mentioned by Hendriana, Rohaeti, and Sumarmo (2017), is to make students use reasoning abilities, In general, students are expected to be able to do mathematical manipulation, compile evidence, explain ideas, and make mathematical statements. Likewise, the 2013 Curriculum aims at developing students' knowledge, thinking, and psychomotor skills through observing, asking questions, gathering information, associating or analyzing, and communicating what they find in analysis activities (Permendikbud No. 81 A, 2013).

One of the thinking skills in the 2013 Curriculum that needs to be developed is mathematical abilities, especially mathematical reasoning ability. In general, the reasoning is divided into two types, namely inductive and deductive reasoning. According to Firdaus (2013), inductive reasoning draws conclusions based on several examples, observations, or experiments. This is supported by Herdian (2010) who stated that inductive reasoning is an individual's reasoning ability at the stage of concrete operations. Furthermore, Soekadijo in Putri $(2011$, p. 35) stated that inductive reasoning consists of three types, namely generalization, analogy, and causation.' Adjie in Miradiyani (2012) stated that learning of mathematics will be easily understood with the reasoning ability. Andriana in Fauziah (2016, p. 2) mentioned that reasoning produces knowledge related to thinking activities rather than feeling activities. Thinking is an activity to find true knowledge. Based on these opinions, it is clear that if you want to improve students learning outcomes, the reasoning ability of students also must be developed.

The fact in the field showed that students' mathematical reasoning ability is still low. This is supported by the research results of Sulistiawati (2014), which revealed that the low ability of students' mathematical reasoning was due to a lack of active students involved in learning mathematics. Likewise, according to Nasution (in Fuad et al., 2016), the low ability of students mathematical reasoning was affected by the provision of instructional material by teachers, which is only equipped with examples and practices about routine problems so that students have difficulty when working on questions about non-routine problems. Moreover, Wahyudin in Mikrayanti (2016) found that one of the tendencies caused a number of students to fail to master mathematical subjects was due to a lack of students' logical reasoning in solving mathematical problems. These will become a problem for teachers and students in the learning process.

The enhancement of primary school students' mathematical reasoning ability is considered as a suitable solution in overcoming students' problems. This is done by applying the ConcretePictorial-Abstract (CPA) approach. The CPA approach is chosen as it has compatibility with the stages of cognitive development of primary school students. The CPA approach is also often referred to as the Concrete-Representational-Abstract (CRA) approach or the 
Concrete-Semi Concrete-Abstract (CSA) approach. The CPA approach is a learning approach based on the concept of Bruner's learning theory regarding the stages of the cognitive development theory of "enactive-iconic-symbolic" cognitive development. As stated above, Putri (2017) revealed that the Concrete-Pictorial-Abstract (CPA) approach consists of three stages, namely (1) Concrete stage, which shows that students solve mathematical problems through physical concrete objects or tangible objects; (2) Pictorial stage, which shows that students use objects through image representation of concrete object manipulation; (3) Abstract stage, which shows that students use symbols or notationsabstract notation. The three stages are in accordance with the theory of cognitive development proposed by Jean Piaget, which states that primary school-age children in fifth grade are at a concrete operational stage, At this stage, children can further think or manipulate tangible objects compared to children at the preoperational stage. Sumartini and Priatna (2018) also confirmed that the patterns of thinking start from concrete thinking to abstract thinking.

It can be concluded that the objectives of this research are: 1) To determine whether there is an effect of the Concrete-Pictorial-Abstract (CPA) approach on the achievement and enhancement of mathematical reasoning ability of primary students; 2) To comprehensively understand the achievement and enhancement of mathematical reasoning ability of primary school students between those who get learning with the CPA approach and those who get conventional learning based on all students reviews and a category of Beginning Prior Mathematical Ability (PMA) (high, moderate, and low).

Before conducting the research, several studies related to mathematical reasoning ability were collected. Ayal et al. (2016) in their research about the enhancement of mathematical reasoning ability of junior high school students through the application of mind mapping strategies revealed that students' who learn using Mind Mapping Strategy have an average of enhancement of mathematical reasoning ability on a moderate level. Likewise. Ginting et al. (2018) in the research of the improvement of mathematical reasoning ability of primary school students using Indonesian Realistic Mathematic Education (IRME) approach found that students who use IRME approach have better achievement and improvement compared to the students who learn using conventional learning. Furthermore, Bernard and Chotimah (2018) in their research regarding the use of the open-ended approach for improving students' mathematical reasoning ability revealed that the learning with an openended approach using a visual basic application for PowerPoint have a better achievement compared to conventional learning. From previous studies, there is an interest in researching by using Concrete-Pictorial-Abstract (CPA) approach. Previous studies revealed that the CPA is able to enhance students' learning achievement, especially mathematical reasoning ability. Putri et al. (2017) showed that primary school students' problem-solving ability can be 
Hafiziani Eka Putri et al., Influence of Concrete-Pictorial-Abstract (CPA) Approach ...

improved using the CPA approach. Putri et al. (2020) also said that inferential data analysis suggests the significant effect of Concrete-Pictorial-Abstract (CPA) implementation on the decrease of students' mathematical anxiety in primary school. Canada Ministry of Education for Ontario (2014) also explains the involvement of the CPA approach in dealing with students' spatial reasoning abilities is like manipulating objects, visualizing, creating or designing objects, and finding solutions for some mathematical problem by imagining objects or numbers proportionally. Rahmat (2014) on his thesis said that the improvement of junior high school students' mathematical reasoning ability who used the CRA approach has been included in moderate criteria, while students' mathematical reasoning ability by using conventional learning has been included in low criteria. This research also measures the influence of the CPA approach on the enhancement of primary school students' mathematical reasoning ability.

\section{METHOD}

This research is a quasi-experimental research with a nonequivalent pretest-posttest control group design. Ruseffendi (2010) described the design of this research as follows:

O $\mathrm{x} \quad \mathrm{O}$

$0 \quad 0$

Information:

$\mathrm{O}=$ Test of mathematical reasoning ability (pretest and posttest)

$X=$ Learning mathematics using the CPA approach

This research examined the differences in the enhancement of students' mathematical reasoning abilities in which the experimental group used CPA learning, while the control group used conventional learning. The experimental and the control groups were given a pre-test. Then, the two classes got treatment with the design of four meetings, based on the distance of time. Afterward, at the end of learning, students in both study groups worked on the final test (post-test) using the same indicators and items. A split technique was used to select the experimental and the control groups by dividing it equally, i.e. each study group, there were high-achiever and mid-achiever students with an almost equal or even number of students. High-achiever and mid-achiever students were categorized based on the achievements or the value of the students' learning outcomes. In addition to examining differences in enhancing students' mathematical reasoning abilities, this research also aimed at developing and improving students' mathematical reasoning ability in primary school. To find out the influence of the learning with the CPA approach and conventional learning in developing and enhancing students 'mathematical reasoning abilities, this research took into Prior Mathematical Ability (PMA) factors. The initial mathematical abilities of students in both groups (experimental and control) were obtained from the results of the PMA test given before conducting learning. Furthermore, students in both study groups were given a pre-test 
of mathematical reasoning ability. At the end of learning, students in both study groups were given a post-test of mathematical reasoning ability. In this research, the initial and final tests used the same indicators and item types.

\section{Research Subject}

The population in this research were all primary school students in Puwakarta, Subang, Karawang, and Bekasi (PURWASUKASI) of West Java Province. The population was selected based on the consideration that primary school students in every school in PURWASUKASI were accepted through a single entry selection system, hence researchers assume that students in each school had the same basic characteristics and abilities. In other words, all members of the population had the same basic abilities.

The research sample was fifth-grade students at two public primary schools in Cikarang. The sample was determined using a purposive sampling technique based on certain considerations (Sugiyono, 2012, p. 124), which are 1) there are limited time and distance so that two primary schools were selected due to their close location; 2) fifth-grade students are familiar with the atmosphere of learning in the classroom, it is assumed that they have passed the transition period related to the atmosphere and rhythm of learning from kindergarten to primary school; 3) both selected primary schools had the same Accreditation, namely Accreditation B. There are many primary schools with Accreditation B in PURWASUKASI, therefore the results of this research are expected to be able to generalize mathematical reasoning ability of students with the same characteristics.

The sample subjects were 121 students divided into two groups, namely the experimental group consisted of 59 students, and the control group consisted of 62 students. Students in the experimental group were given learning with the CPA approach, while students in the control group were given conventional learning.

\section{RESULTS}

\section{Prior Mathematical Ability (PMA)}

To find out more detailed descriptions of PMA students based on PMA groups, the average calculation $\overline{\boldsymbol{x}}$ and the standard deviation was calculated for students based on PMA groups. Recapitulation of PMA test results based on learning in terms of the PMA group can be seen in Table 1. The data in Table 1 shows that the average $\bar{x}$ and standard deviation between the PMA test scores of students who had learned with the CPA approach and students who had conventional learning in terms of the PMA group is relatively not much different. In this case, the average PMA score of students who had conventional learning was slightly higher than students who had to learn with the CPA approach, except for the moderate PMA group. The standard deviation of the PMA score of students who had to learn with the CPA approach 
Hafiziani Eka Putri et al., Influence of Concrete-Pictorial-Abstract (CPA) Approach ...

was slightly higher than students who had conventional learning, except for the high PMA group.

Inferential analysis was conducted to find out the equality of groups of students who had to learn with the CPA approach and conventional learning as a whole, and it was reviewed from the PMA group. PMA data equivalence of students will be used to test the achievement and enhancement of students' mathematical reasoning ability. The results of the PMA t-test for the high and Iow PMA groups are presented in Table 2, while the recapitulation of the equality test results (average difference) of the PMA student groups is presented in Table 3. Based on the data in Tables 2 and 3 , it shows that the p-value (sig. 2-way) > from 0.05, then $\mathrm{H}_{0}$ was accepted.

\section{Mathematical Reasoning Ability}

The recapitulation of the results of the analysis of enhancement students' mathematical reasoning ability based on overall learning is presented in Table 4. The data in Table 4 shows that the enhancement of students' mathematical reasoning ability on each indicator in which students who had to learn with the CPA approach was better than students who had conventional learning.

Recapitulation of the average difference test results in enhancing students' mathematical reasoning ability in terms of the PMA group (high, moderate, and low) can be seen in Table 5.

The hypothesis of an average difference test in the enhancement of students' mathematical reasoning ability of the high PMA group:

$\mathrm{H}_{0}: \mu_{1 \mathrm{H}} \leq \mu_{2 \mathrm{H}}$ Enhancement of mathematical reasoning ability of students who have learning with the CPA approach is not better than students who have conventional learning in terms of the high PMA group.

$\mathrm{H}_{1}: \mu_{1 \mathrm{H}}>\mu_{2 \mathrm{H}}$ Enhancement of mathematical reasoning ability of students who have learning with the CPA approach is better than students who have conventional learning in terms of the high PMA group.

The hypothesis for the average difference test in the enhancement of mathematical reasoning ability of the PMA group is:

$\mathrm{H}_{0}: \mu_{1 \mathrm{M}} \leq \mu_{2 \mathrm{M}}$ Enhancement of mathematical reasoning ability of students who have learning with the CPA approach is not better than students who have conventional learning in terms of the moderate PMA group.

$\mathrm{H}_{1}: \mu_{1 \mathrm{M}}>\mu_{2 \mathrm{M}}$ Enhancement of mathematical reasoning ability of students who have learning with the CPA approach is better than students who get conventional learning in terms of the moderate PMA group. 
The hypothesis for the average difference in the enhancement of mathematical reasoning ability for the Iow PMA group:

$\mathrm{H}_{0}: \mu_{1 \mathrm{~W}} \leq \mu_{2 \mathrm{~W}}$ Enhancement of the mathematical reasoning ability of students who have learning with the CPA approach is not better than students who have conventional learning in terms of the low PMA group.

$\mathrm{H}_{1}: \mu_{1 \mathrm{~W}}>\mu_{2 \mathrm{~W}}$ Enhancement of mathematical reasoning ability of students who have learning with the CPA approach is better than students who have conventional learning in terms of the low PMA group.

Test criteria: If the p-value (sig. 1 -way) is less than 0.05 then $\mathrm{H}_{0}$ is rejected, and in other cases, $\mathrm{H}_{0}$ is accepted.

The Influence of Learning with the CPA Approach on Students' Mathematical Reasoning Ability

The relationship between the CPA approach with mathematical reasoning abilities can be seen from the simple linear regression analysis.

The hypothesis of linear regression analysis for the achievement of students' mathematical reasoning ability, namely:

$\mathrm{H}_{0}: \mu_{1}=\mu_{2}$ There is no effect of the Concrete Pictorial-Abstract (CPA) approach on students' mathematical reasoning abilities.

$\mathrm{H}_{1}: \mu_{1} \neq \mu_{2}$ There is an effect of the Concrete-Pictorial-Abstract (CPA) approach on students' mathematical reasoning abilities.

Before conducting data processing, the regression equation is determined. According to Sugiyono $(2015$, p. 287), the equation of simple linear regression is as follows:

$$
\hat{Y}=a+\beta X
$$

Information:

$\hat{Y}$ (read: $Y$ cap) $=$ Dependent variable

$a=$ Constant

$\beta=$ Regression coefficient

$\mathrm{X}=$ Free variable

The results of data processing assisted by Statistical Product and Service Solutions (SPSS) version 22, which are presented in Table 6, show that the regression equation $\hat{Y}=0.803+$ $0.465 \mathrm{X}$ was obtained. Furthermore, to determine the magnitude of the influence of independent variables on the dependent variable, it is necessary to test the coefficient of determination. The coefficient of determination is the same as the value of $R$ Square $\left(R^{2}\right)$. The results of the determination coefficient, which are presented in Table 7, shows that the coefficient of determination (R Square) value of 0.592 or $59.2 \%$ was obtained. This indicates that the magnitude of the influence of learning with the CPA approach on students' 
Hafiziani Eka Putri et al., Influence of Concrete-Pictorial-Abstract (CPA) Approach ...

mathematical reasoning abilities was $59.2 \%$. While the magnitude of the influence of other factors was $40.8 \%$.

Based on the research results, the implications can be stated as follows:

1. Learning with the CPA approach can be applied in Mathematics learning to develop and improve primary school students' mathematical reasoning ability.

2. Learning with the CPA approach can be applied to each PMA group (high, moderate, and low) in developing and improving primary school students' mathematical reasoning ability.

3. In addition to being influenced by the application of learning with the CPA approach, achievement, and enhancement of students 'mathematical reasoning ability are also influenced by the initial students' Prior Mathematical Ability (PMA).

4. Learning with the CPA approach can be applied in fifth grade in enhancing the learning activities of primary school students.

5. Learning with the CPA approach can be applied in mathematics learning on the theme of presenting data (both on data collection and on presentation through diagrams).

Table 1. Recapitulation of Students' PMA Test Scores based on Learning of PMA Groups

\begin{tabular}{ccccccccc}
\hline \multirow{2}{*}{ Learning } & \multicolumn{6}{c}{ PMA Groups } & Ideal \\
\cline { 2 - 7 } & $\overline{3}$ & \begin{tabular}{c} 
High \\
std. \\
\cline { 2 - 7 } deviation
\end{tabular} & $\overline{\boldsymbol{x}}$ & $\begin{array}{c}\text { std. } \\
\text { deviation }\end{array}$ & $\overline{\boldsymbol{x}}$ & $\begin{array}{c}\text { std. } \\
\text { deviation }\end{array}$ & $\begin{array}{c}\text { Maximum } \\
\text { Score }\end{array}$ \\
\hline CPA & 17.40 & 1.17 & 12.17 & 1.45 & 7.63 & 0.92 & 30 \\
\hline Conventional & 18.22 & 1.20 & 11.87 & 1.32 & 7.88 & 0.83 & 30 \\
\hline
\end{tabular}

Table 2. Recapitulation of Average PMA Difference Test for Students in terms of the High and Low PMA Groups

\begin{tabular}{|c|c|c|c|c|c|c|c|}
\hline $\begin{array}{l}\text { PMA } \\
\text { Groups }\end{array}$ & Learning & Average & $t_{\text {calculation }}$ & Df & ttable & $\begin{array}{l}\text { p-value } \\
\text { (sig. 2- } \\
\text { way) }\end{array}$ & Information \\
\hline \multirow{2}{*}{ High } & CPA & 17.40 & & & & & \multirow{3}{*}{$\begin{array}{c}\text { Howas } \\
\text { accepted }\end{array}$} \\
\hline & Conventional & 18.22 & -1.507 & 17 & 2.110 & 0.150 & \\
\hline Low & $\begin{array}{c}\text { CPA } \\
\text { Conventional }\end{array}$ & \begin{tabular}{|l|}
7.63 \\
7.88
\end{tabular} & -0.571 & 14 & 2.145 & 0.577 & \\
\hline
\end{tabular}

Table 3. Recapitulation of the Average PMA Difference Test Students in terms of the Moderate PMA Group

\begin{tabular}{cccccc}
\hline $\begin{array}{c}\text { PMA } \\
\text { Groups }\end{array}$ & Learning & $\begin{array}{c}\text { Mann- } \\
\text { Whitney U } \\
\text { Test }\end{array}$ & $\mathbf{Z}$ & $\begin{array}{c}\text { p-value } \\
\text { (sig. 2- } \\
\text { way) }\end{array}$ & Information \\
\cline { 1 - 2 } Moderate & CPA & 808.000 & -1.011 & 0.312 & $\begin{array}{c}\text { Howas } \\
\text { accepted }\end{array}$ \\
\cline { 2 - 2 } & Conventional & &
\end{tabular}

Table 4. Recapitulation of Students' Mathematical Reasoning Enhancement Ability on Each Indicator based on Learning 


\begin{tabular}{|c|c|c|c|}
\hline No. & Indicator & Learning & N-Gain \\
\hline \multirow{2}{*}{1.} & \multirow{2}{*}{ Make logical conclusion } & CPA & 0.39 \\
\hline & & Conventional & 0.08 \\
\hline \multirow{2}{*}{2.} & \multirow{2}{*}{$\begin{array}{l}\text { Provide an explanation using models, facts, } \\
\text { traits, and relationships }\end{array}$} & CPA & 0.31 \\
\hline & & Conventional & 0.11 \\
\hline \multirow{2}{*}{3.} & \multirow{2}{*}{$\begin{array}{l}\text { Estimate the answer and the solution } \\
\text { process }\end{array}$} & CPA & 0.28 \\
\hline & & Conventional & 0.11 \\
\hline \multirow{2}{*}{4.} & \multirow{2}{*}{$\begin{array}{l}\text { Use patterns and relationships to analyze } \\
\text { mathematical situations }\end{array}$} & CPA & 0.25 \\
\hline & & Conventional & 0.08 \\
\hline
\end{tabular}

Table 5. Recapitulation of Tests for Average Differences in Improving Students' Mathematical Reasoning Ability in terms of the PMA Group

\begin{tabular}{|c|c|c|c|c|c|c|c|}
\hline $\begin{array}{l}\text { Mathematical } \\
\text { Reasoning } \\
\text { Ability Test }\end{array}$ & $\begin{array}{l}\text { PMA } \\
\text { Groups }\end{array}$ & Learning & $\begin{array}{c}\text { Mann- } \\
\text { Whitney } \\
\text { Test }\end{array}$ & & $\mathbf{Z}$ & $\begin{array}{c}\text { p-value } \\
\text { (sig. 1- } \\
\text { way) }\end{array}$ & Information \\
\hline \multirow{2}{*}{ Enhancement } & High & $\begin{array}{c}\text { CPA } \\
\text { Conventional } \\
\end{array}$ & 5.000 & & -3.273 & 0.000 & \multirow{2}{*}{ Horejected } \\
\hline & Moderate & $\begin{array}{c}\text { CPA } \\
\text { Conventional }\end{array}$ & 290.500 & & -5.514 & 0.000 & \\
\hline $\begin{array}{l}\text { Mathematical } \\
\text { Reasoning } \\
\text { Ability Test }\end{array}$ & $\begin{array}{l}\text { PMA } \\
\text { Groups }\end{array}$ & Learning & $\begin{array}{c}\text { tcalculatio } \\
n\end{array}$ & $d f$ & $t_{\text {tabel }}$ & $\begin{array}{l}\text { p-value } \\
\text { (sig. 1- } \\
\text { way) }\end{array}$ & Information \\
\hline Enhancement & Low & $\begin{array}{c}\text { CPA } \\
\text { Conventional }\end{array}$ & 6.301 & 14 & 2.145 & 0.000 & Horejected \\
\hline
\end{tabular}

Table 6. Results of Regression Coefficient Data Processing and General Forms of Regression Equations

\begin{tabular}{ccc}
\hline \multirow{2}{*}{ Model } & \multicolumn{2}{c}{ Unstandardized Coefficients } \\
\cline { 2 - 3 } & B & Std. Error \\
\hline (Constant) & 0.803 & 0.525 \\
\hline Post-test & 0.465 & 0.051 \\
\hline
\end{tabular}

Table 7. Determination Coefficient Test Results

\begin{tabular}{cccc}
\hline $\mathbf{R}$ & $\mathbf{R}$ Square & Adjusted $\mathbf{R}$ Square & Std. Error of the Estimate \\
\hline 0.769 & 0.592 & 0.584 & 1.248 \\
\hline
\end{tabular}

\section{DISCUSSION}

Learning with the CPA approach in this research has been designed to develop and improve students' mathematical reasoning ability. The given assignments are presented in the form of a Student worksheet group (LKK - Lembar Kerja Kelompok). Each LKK is designed to refer to the theme of data collection and presentation, indicators of mathematical reasoning ability, and stages of learning using the CPA approach. Students who follow the implementation of learning with the CPA approach are involved in learning with small groups of 6-8 students with heterogeneous abilities. 
Hafiziani Eka Putri et al., Influence of Concrete-Pictorial-Abstract (CPA) Approach ...

There are several findings during the implementation of learning with the CPA approach in the classroom. At the first meeting of learning using the CPA approach, the students with moderate and Iow PMA were still difficult by what to do. Meanwhile, the students with high PMA were more adaptable to the conditions of learning undertaken, and students with high PMA more actively participated in discussions and helped students with moderate and low PMA in their groups to solve the problems. The difficulty of students to adapt to new learning approaches is foreseeable. This situation is in line with Brune in Yumiati \& Noviyanti (2017) who stated that changes in the learning model require changes in the role of students. Learning with the CPA approach emphasizes the active role of students in developing their knowledge, through the stages of learning by using concrete (manipulative) objects, pictorial stages, and abstract stages. These stages of learning provide opportunities for students to build new knowledge by making connections with knowledge gained by students. The three stages of the CPA supported each other, and the implementation was carried out in an integrated manner. This is consent with the opinion of Riccomini et al. (2008) who stated that CPA should not be seen or practiced as a separate approach but rather as an integrated approach to ensure the success of each student. Likewise, Miller and Mercer (in Sousa, 2007) stated that each stage in the CPA builds on the previous teaching in order to encourage student learning, the ability to remember and to invoke conceptual knowledge. The results found that in general, the increase in mathematical reasoning ability of students who had to learn with the CPA approach was better compared to students who had conventional learning based on all reviews and PMA groups. These results are also in line with the results of Agrawal and Morin's research (2016), which show that CPA is very effective in improving the mathematical abilities of students who have less mathematical abilities, and learning difficulties. Yuliawaty's research results (2011) also show that the increase in mathematical abilities of students who have learning with the CPA approach is better than students who get conventional learning. Therefore, it can be concluded that the application of the CPA approach in learning can develop and enhance students' mathematical reasoning ability compared to conventional learning, both as a whole and in the PMA group. However, to obtain optimal results, it takes time to implement learning with the CPA approach that is longer than the implementation of this research.

The enhancement of the students' mathematical reasoning ability by learning with the CPA approach was significantly better compared to the students with conventional learning because the stages of learning with the CPA approach provide opportunities for students to understand the concepts learning more easily. The first stage by learning with the CPA approach is the use of concrete objects that can be manipulated will be able to help students prepare to learn more abstract concepts. This is in line with Skemp (in Turmudi, 2012) who suggests that the provision of manipulative objects in learning can be used as a basis for 
further learning at a more abstract level. Moreover, Bruner (in Suwangsih \& Tiurlina, 2006) states that interactions with manipulated concrete objects strengthen understanding of concepts, and help students to remember ideas learned more easily, and apply them in real situations appropriately. Furthermore, the second stage of CPA learning, which is a pictorial stage, is showed based on transition students' mathematical ability from concrete objects to symbolic representations (abstract).

Thus, it can be concluded that the application of the CPA approach in learning can further develop and enhance students' mathematical reasoning ability compared to conventional learning applications, both as a whole and in the PMA group. However, to obtain optimal results, it takes time to implement learning with a CPA approach that is longer than the implementation of this research.

\section{CONCLUSION}

Based on the findings and discussion described in the previous section, it can be concluded in general that:

1. The achievement and enhancement of the students' mathematical reasoning ability by learning with the CPA approach were better than the students with conventional learning in terms of overall students. The achievement of students' mathematical reasoning ability in learning with CPA and conventional approaches was in the moderate category. the enhancement of the students' mathematical reasoning ability by learning with the CPA approach was in the medium category, and with conventional learning was in a low category.

2. The achievement and rnhancement of the students' mathematical reasoning ability of students by learning with the CPA approach were better than the students with conventional learning in terms of the high PMA group. The achievement of students' mathematical reasoning ability in learning with CPA and conventional approaches was in the medium category. The enhancement of students' mathematical reasoning ability in learning with the CPA approach was in the medium category, and with conventional learning was in a low category.

3. The achievement and enhancement of the students' mathematical reasoning ability by learning with the CPA approach were better than the students with conventional learning in terms of the PMA group. The achievement of the students' mathematical reasoning ability by learning with CPA and conventional approaches was in the medium category. The enhancement of the students' mathematical reasoning ability in learning with CPA and conventional approaches was in a low category.

4. The achievement and enhancement of students' mathematical reasoning ability by learning with the CPA approach were better than the students with conventional learning in terms of the low PMA group. The achievement of the students' mathematical reasoning 
Hafiziani Eka Putri et al., Influence of Concrete-Pictorial-Abstract (CPA) Approach ...

ability by learning with the CPA approach was in the medium category, and with conventional learning was in a low category. The enhancement of the students' mathematical reasoning ability by learning with CPA and conventional approaches was in a low category.

5. Learning with the CPA approach can be a reference material for teachers in using a learning method that is effective, efficient, and fun. The learning media used are easy to find, especially the CPA approach that can enhance students' mathematics reasoning ability.

6. This research can be considered to be a material of scientific reference for researchers. The research also explained the influence of the CPA approach on the enhancement of students' mathematics reasoning ability in which the results were shown from $R$ Square value of 0,592 , which indicated that, CPA approach had a percentage of influence by $59,2 \%$ towards the enhancement of the students mathematical reasoning ability. Therefore, this can provide oportunities for researchers to find other factors.

\section{REFERENCES}

Agrawal, J., \& Morin, L. L. (2016). Evidence-Based Practices: Applications of Concrete Representational Abstract Framework across Math Concepts for Students with Mathematics Disabilities. Learning Disabilities, 31 (1), 34-44. DOI: 10.1111/ldrp.12093

Ayal, C. S., Kusuma, Y. S., Sabandar, J., \& Dahlan, J. A. (2016). The Enhancement of Mathematical Reasoning Ability of Junior High School Students by Applying Mind Mapping Strategy. Journal of Education and Practice, 7(25), 50-58.

Bernard, M., \& Chotimah, S. (2018). Improve Student Mathematical Reasoning Ability with Open-Ended Approach Using VBA for Power Point. International Conference on Scicence and Applied Science (ICSAS) 2018. [Proceeding]. Faculty of Mathematics and Sciences, Universitas Negeri Sebelas Maret, Surakarta.

Bernard, M., \& Senjayawati, E. (2019). Developing the Students' Ability in Understanding Mathematics and Self-confidence with VBA for Excel. Journal of Research and Advances in Mathematics Education, 4(1), 45-46. DOI: 10.23917/JRAMATHEDU.V111.6349

Canada Ministry of Education for Ontario. (2014). Paying Attention to Spatial Reasoning: Support Documents for Paying Attention to Mathematics Education. Ontario: Queen's Printer for Ontario. [Online]. Accessed from page http://www.edu.gov.on.ca/eng/literacynumeracy/Inspayingattention.pdf.

Depdiknas.(2006). Kurikulum Tingkat Satuan Pelajaran. Jakarta: Depdiknas.

Fauziah, A. R. (2016). Penerapan Pendekatan Concrete-Pictorial-Abstract (CPA) untuk Meningkatkan Kemampuan Penalaran Matemati sSiswa pada Pembelajaran Matematika Sekolah Dasar. (Thesis). PGSD, Universitas Pendidikan Indonesia, Purwakarta.

Firdaus, F. M. (2013). Pengaruh Quantum Learning terhadap Penalaran Matematis Siswa Sekolah Dasar. Jurnal Edu Humaniora. 5(2). Pp. 95-97. DOI: 10.17509/eh.v5i2.2839

Hendriana, H., Rohaeti, E. E., \& Sumarmo, U. (2017). Hard Skills dan Soft Skills Matematik Siswa. Bandung: Refika Aditama. 
Herdian. (2010). Pengaruh Metode Discovery terhadap Kemampuan Analogi dan Generalisas iMatematis Siswa SMP. (Thesis). Post-graduate School, Universitas Pendidikan Indonesia, Bandung.

Mikrayanti. (2016). Meningkatkan Kemampuan Penalaran Matematis melalui Pembelajaran berbasis Masalah. Jurnal Suska Journal of Mathematics Education, 2(2), 97-98. DOI: 10.24014/sjme.v2i2.1547

Miradiyani, V. F. U. (2012). Penerapan Pendekatan Cooperative Learning tipe Team Games Tournament (TGT) untuk Meningkatkan Kemampuan Penalaran Matematik Peserta Didik Sekolah Dasar. (Thesis). PGSD major, Universitas Pendidikan Indonesia, Purwakarta.

Putri, H. E. (2011). Kemampuan Penalaran Matematik dalam Pembelajaran Matematika di SD. Jurnal Metodik Didaktik, 6(1), 33-38.

Putri, H. E. (2017). Pendekatan Concrete-Pictorial-Abstract (CPA), Kemampuan Kemampuan Matematis, dan Rancangan Pembelajarannya. Subang: Royyan Press.

Putri, H. E., Julianti, R., Adjie, N., Suryani, N. E. (2017). Pengaruh Pendekatan ConcretePictorial-Abstract (CPA) terhadap Pencapaian Kemampuan Spatial Sense (KSS) Siswa SD. Metodik Didaktik. 13(1). 42-52. DOI: 10.17509/md.v13i1.7692

Putri, H. E., Muqodas, I., Wahyudy, M. A., \& Nuraeni, F. (2020). The Effect of Concrete-PictorialAbstract CPA) Approach on The Decrease of Mathematical Anxiety in Elementary school. International Conference on Elementary Education. 2(1). 80-93.

Putri, H. E., Rahayu, P., Saptini, R. D., \& Misnarti. (2016). Keterkaitan Penerapan Pendekatan CPA dan Peningkatan Kemampuan Koneksi Matematis Siswa Sekolah Dasar. Universitas Pendidikan Indonesia, Purwakarta. [Online]. Retrieved from http://ejournal.upi.edu/index.php/Metodik/Didaktik/article/view3785. [11 Oktober 2016]http://ejournal.upi.edu/index.php/MetodikDidaktik/article/download/3785/ 2699. [27 September 2017]

Rahmat, F. R. F. (2014). Penerapan Pendekatan Concrete-Representational-Abstract (CRA) untuk Meningkatkan Kemampuan Penalaran Matematis Siswa. (Penelitian Eksperimen pada Siswa Kelas VIII - MTs. N. Wanayasa). [Thesis]. Department of Mathematics Education, Universitas Islam Negeri Sunan Gunung Djati, Bandung.

Fuadi, R., Johar, R., \& Munzir, S. (2016). Peningkatkan Kemampuan Pemahaman dan Penalaran Matematis melalui Pendekatan Kontekstual, Jurnal Didaktika Matematika, 3(1). 47-49.

Riccomini, P. J., Witzel, B., \& Robbins, K. (2008). Improving the Mathematics Instruction for Students with Emotional and Behavioral Disorders: Two Evidenced-Based Instructional Approaches. Beyond Behavior, 17(2), 24-30.

Ruseffendi, E. T. (2010). Basics Education Research \& Field Other Non-exact Sciences. Bandung: Bandung Tarsito.

Ginting, M. S., Prahmana R. C. I., Isa, M., \& Murni. (2018). Improving the Reasoning Ability of Elementary School Student through the Indonesian Realistic Mathematics Education. Journal on Mathematics Education, 9(1), 41-54. DOI: 10.22342/jme.9.1.5049.41-54

Sugiyono. (2012). Metode Penelitian Kuantitatif, Kualitatif, dan Kombinasi (Mixed Methods). Bandung: Alfabeta.

Sugiyono. (2015). Statistik Nonparametris untuk Penelitian. Bandung: Alfabeta. 
Hafiziani Eka Putri et al., Influence of Concrete-Pictorial-Abstract (CPA) Approach ...

Sousa, D. A. (2007). The Concrete-Pictorial-Abstract Approach. [Online]. Accessed from page http://www.loganschools.org/mathframework/CPA.pdf.

Sulistiawati. (2014). Analisis Kesulitan Belajar Kemampuan Penalaran Matematis Siswa pada Mater iLuas Permukaandan Volume Limas. [Proceeding]. Seminar Nasioanal Pendidikan Matematika, Sains, dan TIK STKIP Surya 2014.

Sumartini, T. S., \& Priatna, N. (2018). Identify Student Mathematical Understanding Ability through Direct Learning Model. Journal of Physics: Conference Series, 1132, 1-8.

Suwangsih, E. \& Tiurlina. (2006). Model Pembelajaran Matematika. Bandung: UPI Press.

Turmudi. (2012). Teachers' Perception Toward Mathematics Teaching Innovation in Indonesian Junior High School: An Exploratory Factor Analysis. Journal of Mathematics Education, 5(1), 97-120.

Yuliawaty, L. (2011). Pembelajaran Matematika dengan Pendekatan CRA (ConcreteRepresentational-Abstract) untuk Meningkatkan Kemampuan Pemahaman dan Pemecahan Masalah Matematik Siswa SMP. [Thesis]. Post-graduate School, Universitas Pendidikan Indonesia, Bandung.

Yuniati \& Noviyanti, M. (2017). Analysis of Mathematic Representation Ability of Junior High School Students in the Implementation of Guided Inquiry Learning. Journal of Mathematics Education, 6(2), 137-148. DOI: 10.22460/infinity.v6i2.p137-148 